\section{A Study of Academic Factors Underlying First Grade Retention in Primary Schools of North Khorasan}

\author{
Malahat Amani ${ }^{\mathrm{a},}{ }^{*}$, Rogayeh Asadi Gandomani ${ }^{\mathrm{b}}$, Abas Nesayan $^{\mathrm{c}}$
}

\begin{tabular}{ll}
\hline Received: & 7 October 2019 \\
Revised: $\quad$ & 2 March 2020 \\
Accepted: $\quad$ & 30 March 2020 \\
ISSN: 1307-9298 \\
Copyright @ IEJEE \\
www.iejee.com
\end{tabular}

DOI: 10.26822/iejee.2020459462

\begin{abstract}
The first grade is the cornerstone of the student's education in school. Achievements at this grade wield huge influence on a child's interest and development of a positive attitude towards education and learning environment. The purpose of this study is to investigate the academic factors of first grade retention in primary schools in North Khorasan. In the first study, a causal-comparative method and in the second study, a qualitative method are adopted. The statistical population includes all first-grade students, their teachers, and parents in North Khorasan province. The first study' sample consists of 351 students who were divided into three groups of grade retention, weak academic achievement, and strong academic achievement. The second study consisted of 30 first-grade teachers. Data collection tools included Parental Involvement in the Child's Education Scale, Student-Teacher Relationship Scale, Researcher-Made Questionnaire, and semi-structured interview. The results showed that the parents of students with grade retention and poor academic achievement had limited participation in school activities. Teachers also had more conflicting relationships with weak students that were retained. According to the results of the qualitative method, three components of attitude, cognition, and behaviour in the teaching process served as qualitative subcomponents of difference between teachers of retained students and teachers whose students were not retained. The results have many implications for the prevention and reduction of grade retention, especially in the first grade.
\end{abstract}

Keywords: Grade Retention, First Grade, Academic Factors

\section{Introduction}

Grade retention refers to compelling s student to stay in the same grade for another academic year (Jackson, 1975). Grade retention is a popular yet controversial method for compensating for poor academic performance (McCoy \& Reynolds, 1999). Some teachers and parents believe that by spending more than one year at the same grade, children are encouraged to acquire skills required to succeed at the next level (Jimerson \& Kaufman, 2003). For children who are obliged to repeat a grade on the account of immaturity, it is reasonable to assume that spending time with younger peers and lower expectations would contribute to the child's social and personal adjustment. The purpose of grade retention is to amend academic failure or social immaturity. Many teachers who advocate grade retention practice argue that it is an effective solution to academic failure or incompatibility (Jimerson, Carlson, Rotert, Egeland, \&Sroufe, 1997). It is estimated that approximately 7 to 15 percent of US students go through grade retention every year (Davoudzadeh, McTernan, \& Grimm, 2015). In North Khorasan, in 2018 school year, the rate of grade retention was estimated at $5.25 \%$ at the first grade (North Khorasan Department of Education, 2018). In their study on a large sample of children aged 7 to 17 -years old, Byrd and Weitzman (1994) found that $7.6 \%$ of children fail to pass the first or preschool grade.

Studies on the efficacy of grade retention have shown conflicting results regarding its effect on modifying children's socio-emotional needs and academic achievement. Some studies have found that grade retention improves children's academic performance at the next grade (Hughes, Chen, Thoemmes, \& Kwok, 2010; Vandecandelaere, Vansteelandt, De Fraine, \&Van Damme, 2016). According to some review and meta-analyses, the existing evidence does not support the use of grade retention as an academic intervention
(Holmes, 1989; Jackson, 1975). On the other hand, some studies have not presented any evidence of the beneficial effects of grade retention (Holmes, 1989; Holmes \& Matthews, 1984; Im, Hughes, Kwok, Puckett, \& Cerda, 2013). Grade retention is associated with repeated absences, academic failure, and school dropouts (Andrew, 2014; Ou \& Reynolds, 2010). In a longitudinal study, Hughes, Coa, West, Smith, and Cerda (2017) examined the effects of grade retention at primary school on early dropout at age of 16 , finding that grade retention escalates early dropout and this effect persisted even after controlling the covariance related to academic achievement. Some studies have found that retained children have lower school attendance, poor social adjustment, negative attitudes toward school, behavioural problems, and poor academic achievement compared to their peers. However, other studies have reported less differences between these two groups (Jimerson \& Kaufman, 2003; Jimerson \& Ferguson, 2007). Some studies looked into the role of grade moderator in personal and social adjustment, suggesting that grade retention in the first year is less likely to be associated with adverse effects in subsequent years (Jimerson et al., 1997).

Considering the grave consequences of grade retention, it is necessary to identify the factors influencing grade retention. Yang, Chen, Rhodes, and Orooji (2018), focusing on the variables of financial problems and lack of parental participation in school activities, conducted a longitudinal study on the risk factors of grade retention among primary students, reporting a correlation between grade retention and financial problems. The found that the relationship between grade retention and financial problems is moderated by the variable of participation in school activities. It has been found that parental involvement in school activities is particularly critical in the early years. However, a large number of studies have reported a significant relationship between parental involvement in school activities and test scores (Winsler, Hutchison, 
De Feyter, Manfra, Bleiker, Hartman, \& Levitt, 2012). According to these studies, poor parental involvement in school activities is associated with grade retention (Anderson, Whipple, \& Jimerson, 2003; Jimerson et al., 1997; Byrd \& Weitzman, 1994; Holt \& Garcia, 2005). Another study reported that retained children are more likely to display poor readiness skills in preschool (e.g., Duncan et al., 2007; Huang, 2014; Davoudzadeh et al., 2015).

Parents, teachers, and principals play a vital role in the decision-making process of grade retention. A student's behaviour is believed to influence teacher's evaluation of his / her performance (Pianta \& Steinberg, 1992). Children labelled as challenging by their teachers in the early years of school are at a greater risk of encountering problems throughout the curriculum (Flanagan et al., 2003). Teacher-student conflict is a strong predictor in children' acting out, and negative interactions of teachers and children may propose a higher risk of academic failure. On the other hand, positive educational and emotional experiences at school may help reduce children's risky behaviours (Hamre \& Pianta, 2005; Ladd \& Burgess, 2001). For children that are likely to face school problems, the schoolbased approach of Noam and Herman (2002) emphasizes the importance of establishing early relationships with the teacher. It posits that such relationships provide resources and resilience mechanisms to cope with the effects of problems and conflicts in family relationships. There is a great deal of evidence that teacher-child interactions are valuable to student's performance when these interactions are focused, direct, and intentional, and feedback is provided on the student's performance (Dolezal, Welsh, Pressley, \& Vincent, 2003; Pianta, La Paro, Payne, Cox, \& Bradley, 2002; Torgesen, 2002). Pianta et al. (2002) found that when teachers nurture a more child-centred atmosphere, pre-schoolers' children are more likely to engage in learning tasks. The student's perception of positive attachment to the teacher is a predictor of their greater engagement in the curriculum (Furrer \& Skinner, 2003), higher academic motivation (Roeser, Eccles, \& Sameroff, 2000), and greater academic achievement (Crosnoe, Johnson, \& Elder, 2004; Gregory \& Weinstein, 2004). Perry, Donohue and Weinstein (2007) demonstrated that, if students' individual charac teristics are controlled, in teachers who provide students with more academic, emotional and social support such as show ing interest to students' hobbies and providing challengeable opportunities for learning and positive social relationships, students score higher grades in math and have a more positive perception of educational activities. In general, most stud ies on grade retention suffer from methodological problems, for example, (a) comparing pre-test and post-test outcomes of students with grade retention rather than using a comparison group; b) failing to present the characteristics of comparison groups (Holmes, 1989; Niklason, 1987; Jimerson et al., 1997). The present study aims to identify academic factors involved in grade retention using comparative groups (students with low and high academic achievement) to overcome the methodological limitations of past studies, thereby provided more reliable results on factors influencing grade retention in the first grade.

Given the adverse consequences of grade retention on students' academic motivation and its financial costs, the educational system needs to investigate educational factors influencing grade retention. Identifying academic factors influencing grade retention can provide strategies to diminish this practice. This paper investigates the factors affecting grade retention in forms of two studies. The first study examines the role of parental involvement in school activities, pre-school education, and teacher-student relationships at the first grade retention, and the second study explores the role of teachers' educational processes in grade retention from a qualitative perspective

\section{Study 1}

\section{Method}

We used a causal-comparative method because retained students were compared with their peers who had poor and strong academic achievement.

\section{Sample and Sampling Method}

The study population consisted of all first-grade students studying at the primary schools of North Khorasan Province in 2018-2019 school year (approximately 17,000 students). According to the North Khorasan Department of Education, there are 894 cases of first grade retention in this province. We used the maximum sample size $(n=386)$ and 351 completed data forms were retrieved. In the first part, 128 retained students were randomly selected from different cities of the province. For each of these students, some of their peers with weak and strong academic achievement were randomly selected from the same class. The sample size of each peer group was $n=128$. After data collection and exclusion of incomplete data, the data of 117 retained students, 117 weak students, and 117 strong students were achieved. Thus, the sample size consisted of 351 students.

\section{Instruments}

\section{Researcher-made questionnaire}

This questionnaire was used to collect demographic characteristics such as student gender and age, parental education level, parental occupation, and preschool education

\section{Parental involvement in the child's education scale}

For measuring the participation of parents in school activities, we used some items of Parental Involvement in the Child's Education Scale designed by Walker, Wilkins, Dallaire, Sandler, and Hoover-Dempsey (2005). Cronbach's alpha of this scale has been reported to be between .70 and .90. In the present study, the subscales of parental help and guidance in school assignments, parental knowledge and skills, and parental self-efficacy were used to measure participation in school activities. This questionnaire was translated, matched with the back-translation and a Cronbach's alpha reliability of .91 was obtained for the preliminary study.

\section{Student-teacher relationship scale}

This scale, designed by Koomen, Verschueren, van SchootenJak, and Pianta (2012), contains 28 items and has three subscales of dependency, close relationship, and conflict. The response scale is based on a 5-point Likert scale ( 1 = completely false to 5 = completely true). An internal consistency of .88, .90 and .78 has been reported for the three scales of the close relationship, conflict relation, and dependency, respectively. This questionnaire was translated for the present study, and a Cronbach's alpha of .84 was obtained in the preliminary study.

\section{Procedure}

To observe ethical considerations, an informed consent form was obtained from participants before starting the research. Participants were assured that their private information would not be disclosed to any organization or individual and they would remain anonymous. In this study, parents completed Parental Involvement in the Child's Education scale and demographic information questionnaire, and teachers completed the Teacher-Student Relationship Questionnaire. In this study, data analysis was performed using SPSS software. Given that 
Table 1. Mean and standard deviation of parental involvement in school activities by groups and group differences

\begin{tabular}{|c|c|c|c|c|c|c|c|c|}
\hline \multirow{2}{*}{$\begin{array}{l}\text { Parental Involvement } \\
\text { Components }\end{array}$} & \multirow{2}{*}{ Group } & \multirow{2}{*}{ Mean } & \multirow{2}{*}{$\begin{array}{l}\text { Standard } \\
\text { Deviation }\end{array}$} & \multirow{2}{*}{\multicolumn{2}{|c|}{ Group differences }} & \multirow{2}{*}{$\begin{array}{c}\text { Mean } \\
\text { Differences }\end{array}$} & \multicolumn{2}{|c|}{ ANOVA } \\
\hline & & & & & & & $f$ & $p$ \\
\hline \multirow{3}{*}{ Helping in assignments } & Grade retention & 22.94 & 12.72 & \multirow{2}{*}{ Grade retention } & Weak & $3.79^{*}$ & \multirow{3}{*}{13.32} & \multirow{3}{*}{.0001} \\
\hline & weak & 26.74 & 10.94 & & Strong & $7.76^{*}$ & & \\
\hline & strong & 30.71 & 10.75 & Weak & Strong & $3.97^{*}$ & & \\
\hline \multirow{3}{*}{$\begin{array}{l}\text { Acknowledge and skills } \\
\text { of parents }\end{array}$} & Grade retention & 31.27 & 9.78 & \multirow{2}{*}{ Grade retention } & Weak & 1.89 & \multirow{3}{*}{38.97} & \multirow{3}{*}{.0001} \\
\hline & weak & 33.16 & 7.82 & & Strong & $8.86^{*}$ & & \\
\hline & strong & 40.13 & 6.33 & Weak & Strong & $6.97^{\star}$ & & \\
\hline \multirow{3}{*}{ Efficacy } & Grade retention & 24.85 & 5.36 & \multirow{2}{*}{ Grade retention } & Weak & .97 & \multirow{3}{*}{70.95} & \multirow{3}{*}{.0001} \\
\hline & weak & 25.82 & 4.32 & & Strong & $7.21^{*}$ & & \\
\hline & strong & 32.06 & 5.31 & Weak & Strong & $6.24^{*}$ & & \\
\hline
\end{tabular}

Table 2. Comparison of frequency of pre-school education in different groups of students

\begin{tabular}{|c|c|c|c|c|c|c|}
\hline \multirow{2}{*}{ Variables } & \multirow{2}{*}{ Responses } & \multicolumn{3}{|c|}{ Groups } & \multirow{2}{*}{$x^{2}$} & \multirow{2}{*}{$p$} \\
\hline & & Grade retention & Weak & Strong & & \\
\hline \multirow{2}{*}{ Preschool education } & yes & 65 & 79 & 96 & \multirow{2}{*}{19.05} & \multirow{2}{*}{.0001} \\
\hline & no & 52 & 38 & 21 & & \\
\hline
\end{tabular}

Table 3. Mean and standard deviation of teacher-student relationship components

\begin{tabular}{|c|c|c|c|c|c|c|c|c|}
\hline \multirow{2}{*}{$\begin{array}{l}\text { Teacher-Student Rela- } \\
\text { tionship Components }\end{array}$} & \multirow{2}{*}{ Group } & \multirow{2}{*}{ Mean } & \multirow{2}{*}{$\begin{array}{l}\text { Standard } \\
\text { Deviation }\end{array}$} & \multirow{2}{*}{\multicolumn{2}{|c|}{ Group differences }} & \multirow{2}{*}{$\begin{array}{c}\text { Mean } \\
\text { Differences }\end{array}$} & \multicolumn{2}{|c|}{ ANOVA } \\
\hline & & & & & & & $f$ & $p$ \\
\hline \multirow{3}{*}{ Dependency } & Grade retention & 14.19 & 3.44 & \multirow{2}{*}{ Grade retention } & Weak & .11 & \multirow{3}{*}{.03} & \multirow{3}{*}{.97} \\
\hline & weak & 14.30 & 3.92 & & Strong & .02 & & \\
\hline & strong & 14.23 & 3.86 & Weak & Strong & .09 & & \\
\hline \multirow{3}{*}{ Close Relationship } & Grade retention & 35.84 & 5.99 & \multirow{2}{*}{ Grade retention } & Weak & .29 & \multirow{3}{*}{17.48} & \multirow{3}{*}{.0001} \\
\hline & weak & 36.13 & 5.58 & & Strong & $4.10^{*}$ & & \\
\hline & strong & 39.94 & 6.19 & Weak & Strong & $3.18^{*}$ & & \\
\hline \multirow{3}{*}{ Conflict } & Grade retention & 27.94 & 8.63 & \multirow{2}{*}{ Grade retention } & Weak & 1.45 & \multirow{3}{*}{4.88} & \multirow{3}{*}{.001} \\
\hline & weak & 26.49 & 8.97 & & Strong & $3.78^{*}$ & & \\
\hline & strong & 24.16 & 10.33 & Weak & Strong & 2.33 & & \\
\hline
\end{tabular}

the present study was a causal-comparative study, one-way ANOVA and Chi-square were used to consider three groups and several dependent variables.

\section{Results}

Demographic characteristics: $62.7 \%$ (220) of participants were male and $37.3 \%$ (131) were female students. Most of participants lived in Bojnord (94), Raz and Jarglan (68), Mane and Samalqan (58), Esfarain (51), Shirvan (39), Bam and Safi Abad (27), Farooj (8), Garme (3) and Jajarm (3). 52.1\% (183) of samples came from rural areas and $47.9 \%$ (168) from urban areas. The mean age of the students was 7.45 years with $\mathrm{SD}=.60$. With regard to parental occupation, the fathers of 123 students were workers, 128 were self-employed, 27 had office job, 60 were farmers and ranchers, and 13 were unemployed. As for mothers, 330 were housewives and 6 were workers. In regard to parental education, 39 of fathers were illiterate, 140 had primary education, 85 had middle-school education, 64 had high-school education, and 23 had diploma. As for mothers, 56 were illiterate, 119 had primary education, 86 had middle-school education, 72 had high school education, and 18 had a diploma.

Table 1 presents the results of the One-Way Analysis of Variance to compare parental involvement components in three groups of weak, strong and retained students. Since there were three groups for comparison, we used the Tukey post hoc test to evaluate the inter-group difference, considering that this test is suitable for comparison of the same-size groups.

As shown in Table 1, in the parental participation variable, there is a significant difference between the three groups in subscale of parental assistance in doing homework so that the parents of retained students offered the lowest assistance and guidance and parents of the strong student group provided the greatest help and guidance. As for the subscale of knowledge and skill, the parents of retained students had the lowest knowledge and skill to aid their children. As for the self-efficacy subscale, parents of retained and weak students displaced lower self-efficacy in helping and participating in school activities compared to the strong group.

Table 2 shows the results of the Chi-square test for comparing the frequency of pre-school education in the groups.

Table 2 shows that the retained students experience preschool education less than the other groups

Table 3 presents the results of One-Way Analysis of Variance test for comparing the components of student-teacher relationships in the groups of retained, weak, and strong students. Tukey post hoc test was used to demonstrate intergroup differences.

According to Table 3, in the teacher-student relationship variable, dependency was not significantly different be- 
Table 4. Attitude component of the teaching process in teachers with and without retained students

\begin{tabular}{ccc}
\hline Sub-components & Teachers with retained students & Teachers without retained students \\
\hline Teaching children & $\begin{array}{c}\text { Being disappointed in teaching students with learning } \\
\text { disabilities and ignoring them; using labels that } \\
\text { discourage them. }\end{array}$ & $\begin{array}{c}\text { Love teaching and children, motivation and efforts to } \\
\text { help children with learning disabilities }\end{array}$ \\
\hline Content & $\begin{array}{c}\text { The scattered content of the math book, the } \\
\text { inconsistency of lines used in writing and reading books, } \\
\text { the heavy and difficult content of the Quran course, and } \\
\text { the final part the reading book }\end{array}$ & $\begin{array}{c}\text { The use of both reading and Quran-based textbooks } \\
\text { reinforces reading. When it comes to reading, the kind of } \\
\text { book they read is not important. }\end{array}$ \\
\hline Descriptive evaluation & $\begin{array}{c}\text { Descriptive evaluation makes students lazy. } \\
\text { Completing evaluation forms and work folders is useless } \\
\text { and time-consuming. }\end{array}$ & $\begin{array}{c}\text { Descriptive evaluation leads to a reduction in student } \\
\text { stress and an accurate recognition of students' talents } \\
\text { and weaknesses. }\end{array}$ \\
\hline
\end{tabular}

tween the three groups, but they were significant different with regard to close relationship and conflict so that retained and weak students had more conflict with teachers than did the strong group. The strong students managed to forge a close relationship with the teacher compared to the other two groups

\section{Study 2}

\section{Method}

In this study, a qualitative approach (the grounded theory method) was used to explore teaching methods employed by the teachers. The grounded theory is an inductive and exploratory method that allows researchers to formulate a new theory rather than rely on existing theories. Systematically formulated based on actual data, this theory is applicable in cases where our knowledge is limited.

\section{Sample and Sampling Method}

The statistical population consisted of all first-grade teachers in Bojnord in 2018-2019 school year. Given the qualitative and the effort to gain rich and in-depth insights into participants' experiences, a limited sample size was selected and sampling was continued until the theoretical saturation was reached. Using purposeful sampling, 30 first-grade teachers were selected. Of these teachers, 20 had retained students in their classes but there were no retained students in the class of other 10 teachers. Data collection continued to reach theoretical saturation.

\section{Instrument}

Semi-structured interviews for teacher evaluation of teaching practices

Given the absence of any standardized questionnaire for the evaluation of teaching practices in the first grade and considering that the use of self-report multiple-choice questionnaires risks biased responses, semi-structured interviews were used for collecting. The interview involved asking questions about the teaching strategies used by teachers to instruct first-grade students. The open-ended questions allowed in-depth assessment of experience, practice, or action processes. Questions were developed according to the results of previous studies on academic factors influencing academic achievement. Most of questions were about teaching methods, teaching tools, motivation strategies, curiosity- arousing methods, creation of positive attitudes and attractive learning environments, evaluation goals, evaluation methods, types of homework, helping of weak students, and classroom management.

\section{Procedure}

After theoretical saturation was reached, the data derived from notes taken during the interviews were coded. Initially we used free coding to assign appropriate codes to various sections of the data, and the data were then categorized into sub-components. The axial coding was used to detect connection between sub-components and data was further decomposed into components. The ethical considerations observed in qualitative research are also applicable to the grounded theory method, including anonymous data collection and confidentiality of the participant's data and non-disclosure of their identity.

\section{Results}

At the end of data collection, all interviews were transcribed, and divided into two separate groups of teachers with retained students and teachers without any retained students. Based on axial coding, three components of attitude, cognition, and behaviour, and based on free coding, sub-components for teaching processes were obtained. The attitude component consisted of sub-components of children's education and descriptive evaluation. The component of cognition, subcomponents consisted of knowledge of children teaching methods, teaching aids, evaluation methods, and helping of weak students. The behavioural comprised sub-components of teaching methods, strategies to motivate students, create a positive attitude in students and stimulate their curiosity as well as the amount and type of assignments, and classroom management. Tables 4 to 6 illustrate the differences between teachers with and without retained students in terms of attitude, cognition and behaviour components of teaching processes.

As shown in Table 4, teachers with retained students in their class grow tired of working with students with learning problems, tend to ignore them by labelling, and make no effort to improve their skills. These teachers hold a negative attitude toward the descriptive evaluation system and completion of educational forms and work folders. On the other hand, teachers without retained students in their class maintain a positive attitude of educational content and the descriptive evaluation system.

Table 5 shows that teachers without retained students have a good command of teaching methods. They always seek to stay updated of the latest advancements in child psychology and teaching practices and never come to class without preparation. They have creative ideas for teaching and designing teaching instruments. They are cognizant of a variety of assessment methods such as self-assessment, peer-assessment, parental and performance assessment. as for weak students, they have sufficient knowledge to identify students' weaknesses and help them overcome these frailties.

Table 6 shows that teachers of retained student often prefer to use more traditional teaching methods, sometimes students are more active in some stages of instruction such as reviewing the lessons and teachers utilize more readily available teaching materials.

On the other hand, teachers without retained students opt for creative and heuristic teaching approaches, and design creatively teaching materials with a student-centred teaching method. They place premium on close relationships with stu- 
Table 5. Cognitive component of the teaching process in teachers with and without retained students in their class

\begin{tabular}{|c|c|c|}
\hline Sub-components & Teachers with retained students & Teachers without retained students \\
\hline Knowledge of children & $\begin{array}{l}\text { Lacking or having inadequate knowledge of child } \\
\text { psychology, paying little attention to students' } \\
\text { knowledge }\end{array}$ & $\begin{array}{l}\text { Good knowledge of children and motivation to } \\
\text { stay up-to-date, understanding students and } \\
\text { discovering their special talents or weaknesses }\end{array}$ \\
\hline Knowledge of Teaching practices & $\begin{array}{l}\text { Knowledge Insufficient Teaching Practices and } \\
\text { Incomplete knowledge of New Teaching methods }\end{array}$ & $\begin{array}{l}\text { Tendency to prepare themselves for a new } \\
\text { teaching method a few days ahead, thorough } \\
\text { study of new teaching methods in the first } \\
\text { grade }\end{array}$ \\
\hline $\begin{array}{l}\text { Knowledge of teaching instru- } \\
\text { ments }\end{array}$ & $\begin{array}{l}\text { Use of playing cards, newspapers, books, tablets, } \\
\text { all tangible objects, consonant-vowels, poetry }\end{array}$ & $\begin{array}{c}\text { Structuring creative educational instruments } \\
\text { based on teacher guides, use of games, poetry } \\
\text { storytelling, display, tangible and accessible } \\
\text { objects }\end{array}$ \\
\hline $\begin{array}{l}\text { Knowledge of Evaluation } \\
\text { Practices }\end{array}$ & $\begin{array}{c}\text { Use of Q\&A, dictation, reading, observation, } \\
\text { workgroups }\end{array}$ & $\begin{array}{l}\text { Use of self-assessment, peer assessment, pa- } \\
\text { rental evaluation at home, functional } \\
\text { evaluation, observations }\end{array}$ \\
\hline $\begin{array}{l}\text { Knowledge of students' weak- } \\
\text { nesses }\end{array}$ & $\begin{array}{l}\text { Giving assignments and drills to be repeated and } \\
\text { practiced, communicating with parents and using } \\
\text { them in the class, teamwork, giving simple assign- } \\
\text { ments, re-teaching, providing hands-on exercises }\end{array}$ & $\begin{array}{l}\text { Identifying student's weaknesses, partnering, } \\
\text { and working with parents to help students, } \\
\text { referring weak students to the Centre for } \\
\text { Learning Disability, giving specific assignments } \\
\text { to students, consulting with a physician and } \\
\text { counsellor for specific strategies }\end{array}$ \\
\hline
\end{tabular}

Table 6. Cognitive component of the teaching process in teachers with and without retained students in their class

\begin{tabular}{|c|c|c|}
\hline Sub-components & Teachers with retained students & Teachers without retained students \\
\hline Teaching methods & Traditional, integrative, teacher-centred, creative & Integrated and sstudent-centred methods \\
\hline $\begin{array}{l}\text { Creating a positive attitude in } \\
\text { students }\end{array}$ & $\begin{array}{l}\text { Encouraging, building confidence, giving respon- } \\
\text { sibility }\end{array}$ & $\begin{array}{c}\text { Making students interested in the learning } \\
\text { environment, participatory learning, discussing } \\
\text { learned things, enhancing students' self-confi- } \\
\text { dence by encouraging and reassuring, excluding } \\
\text { unhealthy competition }\end{array}$ \\
\hline Stimulating students' curiosity & $\begin{array}{l}\text { Developing craftsmanship, storytelling, Q\&A, play } \\
\text { and poetry, assigning challengeable tasks }\end{array}$ & $\begin{array}{l}\text { Paying attention to teacher-student relation- } \\
\text { ship, using storytelling, drama, Q\&A }\end{array}$ \\
\hline Motivating Students & $\begin{array}{l}\text { Speaking, encouraging and giving Stars, teamwork, } \\
\text { designing specific tasks for learning every letter, } \\
\text { taking responsibility, poetry and playing }\end{array}$ & $\begin{array}{l}\text { Storytelling, motivating students to learn a } \\
\text { specific subject, encouraging, sharing teaching } \\
\text { responsibility, displaying love and affection, } \\
\text { using food and supplies during teaching }\end{array}$ \\
\hline $\begin{array}{l}\text { The amount and type of assign- } \\
\text { ments }\end{array}$ & $\begin{array}{l}\text { Giving specific assignments in the book and sup- } \\
\text { plementary pages, assigning homework relative } \\
\text { to the child's ability level, giving targeted and skill- } \\
\text { based assignments, dictation, wording, functional } \\
\text { assignments for math homework }\end{array}$ & $\begin{array}{l}\text { Considering student abilities and rate of learn- } \\
\text { ing assignments, using functional and practical } \\
\text { assignments, giving hand-drawn assignments }\end{array}$ \\
\hline Classroom management & $\begin{array}{c}\text { Setting of classroom rules, group activities, and } \\
\text { participatory sport gestures, motion games, prac- } \\
\text { tising silence, putting the name, granting respon- } \\
\text { sibility, encouragement, behaviour, and respectful } \\
\text { behaviour of the teacher }\end{array}$ & $\begin{array}{c}\text { Preparation before the class, benefiting from } \\
\text { student participation in class, establishing } \\
\text { order, silence practice, slow talk, poetry reading, } \\
\text { and touching }\end{array}$ \\
\hline
\end{tabular}

dents to stimulate a sense of curiosity, motivate students and construct an interesting learning environment. They do not set strict rules in the classroom and prefer functional assignments. Teachers without retained students try to make students more interested in learning and eliminate unhealthy competition in the classroom.

\section{Discussion and conclusion}

The purpose of this research was to investigate the educational causes of first grade retention in primary schools of North Khorasan. The results of the first study showed that in the parental involvement variable, there was a significant difference between the three groups in terms of parental help and guidance for homework, so that the parents of students in the grade retention group offered the lowest level of help and guidance, knowledge, skill, and self-efficacy to help their children. Studies suggest that greater parental involvement in educational activities is associated with lower risk of grade retention (Holt \& Garcia, 2005). Studies have also suggested that poor parental involvement in school activities is linked to grade retention (Anderson et al., 2003;
Jimerson et al., 1997; Byrd, \& Weitzman, 1994). It has been shown that parental involvement in school activities is particularly critical in the early schooling years. However, the bulk of studies have reflected the significant relationship between parental involvement in school activities and academic achievement (Winsler et al., 2012).

Given that in this study the parents of weak and retained students came from a low socioeconomic background, this could reduce the extent of student participation at school. That is, researchers found that patterns of student involvement in school were related to socioeconomic background of the family (Ashiabi, 2005; Garcia \& Guerra, 2004). In the absence of sufficient economic resources, children struggle with a host of challenges like emotional well-being, health, and cognitive development, which may negatively impact school engagement. Families in the grip of financial problems usually have limited resources and greater stress, which takes a toll on the time and attention allocated to educational needs of children. Material problems such as inappropriate studying environments, lack of proper transportation or school uniforms as well as nutrition can de- 
crease the levels of school involvement, which in turn has a bearing on academic performance and grade retention. Studies have shown that students with poor socioeconomic status are more likely to skip school (Morrissey, Hutchison, \&Winsler, 2014), and display undesirable academic performance (Dearing, McCartney, \& Taylor, 2011).

The results of this study showed that retained students barely attended any preschool program. It has been shown that poor pre-school preparation skills are a predictor of grade retention (Shiralipour, Asadi, Nazari, \& Shakuri, 2013; Duncan et al., 2007; Huang, 2014; Davoudzadeh et al., 2015). In this regard, Wang and Johnston (1997) examined the effectiveness of a preschool program by comparing three groups of students: those who had enrolled in preschool, students who had not participated in any preschool program and students who failed the first grade. They found that the preschool program was effective, because the training provide in the preschools developed children's experiences. This in turn enhanced cognitive and social functioning and improved children's preparedness and enthusiasm for school, early academic success, and school skills acquisition. Various studies have demonstrated the positive impact of preschool program and preparation courses on students' performance and academic achievement at school (Shiralipour, Asadi, Nazari, \& Shakuri, 2013). First grade is a student's first experience of academic environment, and the teacher had an enormous effect on shaping students' attitude. According to the results of the present study, in the teacher-student relationship variable, the component of dependency was not statistically different between the three groups, but they were significantly different in the component of close relationship and conflict between, so that retained and weak students were significantly different from the strong students. Retained and week students were in conflict with the teacher while strong students managed to forge a close relationship with the teacher compared to the other two groups.

Consistent with the present study, Ari, Tunçer, and Demir (2016) reported that successful teachers build close relationships with the students. Hamre and Pianta (2005) found that students at the risk of academic failure, who receive teacher's emotional and educational support, displayed better academic achievement and improved teacher-student relationships. Students who form a warm and intimate relationship with their teachers are more motivated to learn, have a greater self-confidence, and take interest in their teacher (Andrzejewski, \& Davis, 2008). Social bonding with teachers is negatively associated with grade retention and school dropout (Catalano, Haggerty, Oesterle, Fleming, \& Hawkins, 2004). Teacher's caring behaviour has been shown to promote prosocial beliefs in students and motivate them to engage actively in the class (Wentzel \&Wigfield, 1998). Developing prosocial connections with adults at school can exert social control, thereby encourage positive behaviours and punish negative conducts (Catalano et al., 2004).

Based on the school-based approach of Noam and Herman (2002), which emphasizes the importance of building early relationships with teachers for children prone to educational problems, appropriate teacher-student relations act as a source of resilience, enabling them to cope with problems in family relationships. Studies suggest that positive schoolbased educational and social experiences help reduce the risk of behavioural problems, while adverse interactions teacher-children between may take a toll on children at high risk of educational failure (Hamre \&Pianta, 2001; Ladd \& Burgess, 2001). In line with the present study, Perry et al. (2007) revealed that students of teachers who provide more emotional and social support to students (e.g., pay attention to their interests, provide challenging learning opportunities and positive social relationships, etc.), score higher grades in math and hold a more positive attitude toward educational activities. As for the qualitative results obtained from the second study, three components of attitude, cognition, and behav- iours were derived from axial coding and subcomponents of teaching processes was achieved from free coding. The subcomponents of attitude consisted of children's education content and descriptive evaluation. In the cognitive component, subcomponents consisted of knowledge of children teaching methods, teaching aids, evaluation methods of weak students. The behavioural component comprised subcomponents of teaching methods, students' motivation, creation of a positive attitude in students, stimulation of curiosity, the amount and type of assignments, and classroom management.

Consistent with the study of Salsabili and Ghasemi (2005), teachers of retained students in the present study stated that the content of textbooks was scattered and difficult for some students to understand. Also, since they have limited time to teach, they have trouble following the materials specified in the book. Teachers of retained students hold a negative attitude towards the descriptive evaluation system due to their lack of knowledge of descriptive evaluation. They believe that filling out educational forms and work folders as time-consuming and futile, arguing that descriptive assessment makes students lazy. They point that the parents of poor students are less likely to cooperate with them. Moreover, teachers of retained students prefer to use traditional teaching methods and are reluctant to identify the flaws of their teaching or use more effective teaching methods. Since teachers of retained students are less student-centred, this can affect student engagement in homework and academic performance, making them less active during teaching. In this regard, studies reveal that students not involved in learning and classroom environments are less likely to progress at school and more susceptible to dropout (Henry, Knight, \& Thornberry, 2102; Rhodes, 2011). Research has shown that school involvement affects academic achievement (Galla, Wood, Tsukayama, Har, Chiu, \& Langer, 2014; Wang \& Holcombe, 2010).

Also, the present study showed that teachers without retained students maintain a positive attitude towards educational content and descriptive evaluation system. They believe that the descriptive evaluation system allows accurate recognition of students and reduces score stress. To them, filling out educational forms and folder work is not useless and waste of time. They are eager to learn and seek to update their knowledge on child psychology and teaching practices, prepare themselves before class, come up with creative teaching ideas and apply them in the class. These teachers work on reading and writing skills of first-grade students and strive to foster creativity and talents of their students. Their students interact well with parents and are they opt for a student-centred approach to teaching and class management. Similarly, Pianta et al. (2002) found that when teachers build a more student-centred atmosphere, pre-schoolers are more likely to engage in learning tasks. The perception of positive dependence on teachers by students is a predictor of engagement with the curriculum (Furrer \& Skinner, 2003), enhanced academic motivation (Roeser et al., 2000) and greater academic achievement (Crosnoe et al., 2004; Gregory \& Weinstein, 2004). According to Reeve's (2012) approach, student-centred teachers promote the learning environment and encourage students to be actively involved in learning. Research suggests that school involvement is a strong predictor of academic outcomes in both cross-sectional and longitudinal studies (e.g. Li-Grining, Votruba-Drzal, Maldonado-Carreno, \& Haas, 2010). Most importantly, teachers without retained students enjoy spending time with first-grade students. These teachers usually employ creative and heuristic teaching methods, and prefer making use of creatively designed teaching aids. To stimulate a sense of curiosity and motivation and to stress the importance of building close relationships with students, they do not set strict rules for the classroom and adopt functional assignments and environmentally relevant assignments. They attempt to make students more interested in learning and diminish unhealthy competition in the classroom. They recruit a variety of evaluation methods such as self-assessment, peer-assessment, pa- 
rental and performance assessment. As for weak students, teachers try to identify their weaknesses and if they fail to help a student, he/she would be referred to a training centre or experts for consultation, and they avoid sticking labels to these students. Therefore, students of teachers who provide more education, emotional and social support to students often gain higher scores, and develop more positive attitudes toward educational activities (Perry et al., 2007).

It seems that teachers without retained students employ more effective teaching methods. The following are characteristic of effective teachers: they spend more time for teaching first grade students and utilize different teaching strategies. They tend to adjust the teaching style to suit the whole class, small groups, and individual students. They do not suffice to explaining and modelling but also monitor the progress of students to see how students apply the learned acknowledge and help them if needed. Moreover, effective teachers often use positive motivation. They use various points for teaching to support students' academic motivation (for example, they give reward to successful students, giving them the impression that their success is the outcome of the their own efforts), tailor assignments to students' abilities and forge a link between learning materials. Finally, effective teachers are good at classroom management, rarely use strict disciplinary rules, the class program flows smoothly so that an observer can barely understand the classroom management plan (Bohn, Roehrig, \& Pressley, 2004; Ari et al., 2016).

Given the low parental involvement in school activities of weak and retained students, it is advised to hold meetings with these parents to promote their collaboration with teachers and school principals as a way of advancing the children's education. Given the impact of pre-school education on grade retention, it is recommended to make pre-school programs compulsory for all students and the performance of preschool centres should be monitored for teaching preparation skills. It is necessary to boost teachers' acknowledge of the descriptive evaluation and effective and creative teaching practices and teachers' evaluation should be based on their acknowledge and application of these ways. It is recommended to identify vulnerable children-children with family and financial problems, slow learning, learning disorders, emotional-behavioural problems- in the first months of school year to provide prompt interventions and to prevent grade retention. When selecting and recruiting teachers, especially for the first grade, the willingness and interest in working with children, patience, teaching passion and sufficient knowledge of children, as well as the adoption of effective teaching methods should be taken into account.

This study, like other research papers, had some limitations. Using self-report tools for parent and teacher may lead to biased responses. A standardized questionnaire was not available for examining teachers' teaching style in the first grade, and the use of other teaching questionnaires caused bias in response. Although the causal-comparative method was used to obtain causal results, it was not included in the experimental designs, and therefore the underlying causes of grade retention might not be accurate. The present study was conducted in the primary schools of North Khorasan Province, so caution should be exercised in generalizing the findings. Given the limitations of the study, it is suggested to assess students for individual characteristics at the beginning of each school year, and monitor teaching methods regularly during and at the end of each school year. It is also recommended to draw a comparison between retained students and successful students. Future studies can explore the causes of grade retention and dropout.

\section{Acknowledgment}

This article is extracted from a research project on the causes of first grade retention in primary schools of North Khorasan province, which was funded by the North Khorasan Department of Education. We would like to thank all the teachers and parents of students participating in this research, as well as the stuff of the North Khorasan Department of Education who assisted us throughout this research.

\section{References}

Anderson G. E., Whipple, A.D., \& Jimerson, S. R. (2003), grade retention: achievement and mental health outcomes. http://www.fmptic.org/download/grade_ retention_achievement_and_mental_health_outcomes.pdf

Andrew, M. (2014). The scarring effects of primary-grade retention? A study of cumulative advantage in the educational career. Social Forces, 93(2), 653-685.

Andrzejewski, C. E., \& Davis, H. A. (2008). Human contact in the classroom: Exploring how teachers talk about and negotiate touching students. Teaching and Teacher Education, 24(3), 779-794.

Ari, E., Tunçer, B. K., \& Demir, M. (2016). Primary School Teachers' Views on Constructive Classroom Management. International Electronic Journal of Elementary Education, 8(3), 363-378.

Ashiabi, G. (2005). Household food insecurity and children's school engagement. Journal of Children and Poverty, 11(1), 3-17.

Bohn, C.M., Roehrig, A. D., \& Pressley, M. (2004). The First Days of School in the Classrooms of Two More Effective and Four Less Effective Primary-Grades Teachers. The Elementary School Journal, 104(4), 269-287.

Byrd, R. S., \& Weitzman, M. L. (1994). Predictors of Early Grade Retention Among Children in the United States. Pediatrics, 93(3), 481-487.

Catalano, R. F., Haggerty, K. P., Oesterle, S., Fleming, C.B., \& Hawkins, J. D. (2004). The importance of bonding to school for healthy development: findings from the Social Development Research Group. Journal of School Health, 74(7), 252-261.

Crosnoe, R., Johnson, M. K., \& Elder, G. H. (2004). School size and the interpersonal side of education: An examination of race/ethnicity and organizational context. Social Science Quarterly, 85(5), 1259-1274.

Davoudzadeh, P., McTernan, M. L., \& Grimm, K. J. (2015). Early school readiness predictors of grade retention from kindergarten through eighth grade: A multilevel discrete-time survival analysis approach. Early Childhood Research Quarterly, 32, 183-192.

Dearing, E., McCartney, K., \& Taylor, B. A. (2001). Change in family income-to-needs matters more for children with less. Child Development, 72(6), 1779-1793.

Dolezal, S. E., Welsh, L. M., Pressley, M., \& Vincent, M. M. (2003). How nine third-grade teachers motivate student academic engagement. The Elementary School Journal, 103(3), 239-267. 
Duncan, G. J., Dowsett, C. J., Claessens, A., Magnuson, K., Huston, A. C., Klebanov, P., Pagani, L. S., et al. (2007). School readiness and later achievement. Developmental Psychology, 43(6), 1428-1446.

Flanagan, K. S., Bierman, K. L., Kam, C., Coie, J. D., Dodge, K. A., Foster, E. M., et al. (2003). Identifying at-risk children at school entry: The usefulness of multibehavioral problem profiles. Journal of Clinical Child and Adolescent Psychology, 32(3), 396-407.

Furrer, C., \& Skinner, E. (2003). Sense of relatedness as a factor in children's academic engagement and performance. Journal of Educational Psychology, 95(1), 148-162.

Galla, B. M., Wood, J. J., Tsukayama, E., Har, K., Chiu, A. W., \& Langer, D. A. (2014). A longitudinal multilevel model analysis of the within-person and between-person effect of effortful engagement and academic self-efficacy on academic performance. Journal of School Psychology, 52(3), 295-308.

Garcia, S. B., \& Guerra, P. L. (2004). Deconstructing deficit thinking: Working with educators to create more equitable learning environments. Education and Urban Society, 36(2), 150-168.

Gregory, A., \& Weinstein, R. S. (2004). Connection and Regulation at Home and in School: Predicting Growth in Achievement for Adolescents. Journal of Adolescent Research, 19(4), 405-427.

Hamre, B. K., \& Pianta, R. C. (2005). Can instructional and emotional support in the first grade classroom make a difference for children at risk of school failure?. Child Development, 76(5), 949-967.

Henry, K. L., Knight, K. E., \& Thornberry, T. P. (2012). School disengagement as a predictor of dropout, delinquen$c y$, and problem substance use during adolescence and early adulthood. Journal of Youth and Adolescence, $41(2), 156-166$

Holmes, C. T. (1989). Grade-level retention effects: A meta-analysis of research studies. In L. A. Shepard \& M. L. Smith (Eds.), Flunking grades: Research and policies on retention (pp. 16-33). London: The Falmer.

Holmes, C. T., \& Matthews, K. M. (1984). the effects of nonpromotion on elementary and junior high school pupils: a meta-analysis. Reviews of Educational Research, 54(2), 225-236.

Holt, C. B., \& Garcia, P. (2005). Preparing teachers for children in poverty: The Nashville district picks up the mantle for qualified instruction in high-needs schools. The School Administrator, 62(11), 22-25.

Huang, F. L. (2014). Further understanding factors associated with grade retention birthday effects and socioemotional skills. Journal of Applied Developmental Psychology, 35(2), 79-93.

Hughes, J. N., Chen, Q., Thoemmes, F., \& Kwok, O. (2010). An Investigation of the Relationship between Retention in First Grade and Performance on High Stakes Tests in Third Grade. Educational Evaluation and Policy Analysis, 32(2), 166-182.

Hughes, J. N., Cao, Q., West, S.G., Smith, P. A., \& Cerda, C. (2017). Effect of retention in elementary grades on dropping out of school early. Journal of School Psychology, 65, 11-27
Im, M. H., Hughes, J. N., Kwok, O. M., Puckett, S., \& Cerda, C. A. (2013). Effect of retention in elementary grades on transition to middle school. Journal of school psychology, 51(3), 349-365

Jackson, G. (1975). The research evidence on the effects of grade retention. Review of Educational Research, 45(4), 613-635.

Jimerson, S., Carlson, E., Rotert, M., Egeland, B., \& Sroufe, L. A. (1997). A prospective, longitudinal study of the correlates and consequences of early grade retention. Journal of School Psychology, 35(1), 3-25.

Jimerson, S. R., \& Ferguson, P. (2007). A Longitudinal Study of Grade Retention: Academic and Behavioral Outcomes of Retained Students through Adolescence. School Psychology Quarterly, 22(3), 314-339.

Jimerson, S. R., \& Kaufman, A. M. (2003). Reading, writing, and retention: A primer on grade retention research. (00340561). Reading Teacher, 56(7), 622-635.

Koomen, H. M. Y., Verschueren, K., van Schooten, E., Jak, S. \& Pianta., R. C. (2012). Validating the Student-Teacher Relationship Scale: Testing Factor Structure and Measurement Invariance across Child Gender and Age in a Dutch Sample. Journal of School Psychology, 50(2), 215-234.

Ladd, G. W., \& Burgess, K. B. (2001). Do relational risks and protective factors moderate the linkages between childhood aggression and early psychological and school adjustment? Child Development, 72(5), 1579-1601.

Li-Grining, C. P., Votruba-Drzal, E., Maldonado-Carreno, C., \& Haas, K. (2010). Children's early approaches to learning and academic trajectories through fifth grade. Developmental Psychology, 46(5), 1062-1077.

McCoy, A. R., \& Reynolds, A. J. (1999). Grade retention and school performance: An extended investigation. Journal of School Psychology, 37(3), 273-298.

Morrissey, T., Hutchison, L. A., \& Winsler, A. (2014). Family income, school attendance, and academic achievement. Developmental Psychology, 50(3), 741-753.

Niklason, L. (1987). Do certain groups of children profit from a grade retention?. Psychology in the Schools, 24, 339345.

Noam, G.G, \& Hermann, C.A. (2002). Where education and mental health meet: developmental prevention and early intervention in schools. Development and Psychopathology, 14(4), 861-75.

Ou, S.R., \& Reynolds, A. J. (2010). Grade retention, postsecondary education, and public aid receipt. Educational Evaluation and Policy Analysis, 31(1), 118-139.

Perry, K. E., Donohue, K. M., \& Weinstein R. S. (2007). Teaching practices and the promotion of achievement and adjustment in first grade. Journal of School Psychology, 45(3), 269-292.

Pianta, R. C., La Paro, K. M., Payne, C., Cox, M. J., \& Bradley, R. (2002). The relation of kindergarten classroom environment to teacher, family, and school characteristics and child outcomes. The Elementary School Journal, 102(3), 225-238

Pianta, R., \& Steinberg, M. (1992). Teacher-child relationship and process of adjusting to school. New Directions for Child Development, 57, 61-80. 
Reeve, J. (2012). A self-determination theory perspective on student engagement. In S. Christenson, A. Reschly, \& C. Wylie (Eds.). Handbook of research on student engagement (pp. 149-172). New York, NY: Springer.

Rhodes, J. (2011). The predictive ability of demographic and psychosocial risk factors, school related characteristic, and service interventions on grade attainment among at-risk elementary school children in a truancy intervention program (Doctoral Dissertation) Louisiana State University.

Roeser, R. W ., Eccles, J. S., \& Sameroff, A. J. (2000). School as a Context of Early Adolescents' Academic and Social-Emotional Development: A Summary of Research Findings. The Elementary School Journal, 100(5), 443-471

Salsabili, N., \& Ghasemi, N. (2005). factors affecting school failure: revisiting the internal and external agents. Journal of Education, 21(3), 25-59. (In Persian) https:// www.sid.ir/En/Journal/ViewPaper.aspx?|D=73750

Shiralipour, A., Asadi, M., Nazari, A., \& Shakuri, Z. (2013). A study of meta analysis of role of pre-school education and bilingualism in education achievement. Journal of Educational Sciences, 20(1), 131-154. (In Persian) http://education.scu.ac.ir/article_10107_ en.html

Torgesen, J. K. (2002). The Prevention of Reading Difficulties. Journal of School Psychology, 40(1), 7-26.

Vandecandelaere, M., Vansteelandt, S., De Fraine, B., \&Van Damme, J. (2016). The effects of early grade retention: Effect modification by priorachievement and age. Journal of School Psychology, 54, 77-93.

Walker, J. M. T., Wilkins, A.S., Dallaire, J. R., Sandler, H. M., \& Hoover-Dempsey, K. V. (2005). Parental Involvement: Model Revision through Scale Development. The Elementary School Journal, 106(2), 85-104.

Wang, M. T., \& Holcombe, R. (2010). Adolescents' perceptions of school environment, engagement, and academic achievement in middle school. American Educational Research Journal, 47(3), 633-662.

Wang, Y. L., \& Johnstone, W. (1997). Evaluation of a Pre-First Transitional Program. ERS Spectrum, 15(3), 40-47. (ERIC Documentation Reproduction Services No. ED409348).

Wentzel, K. R., \&Wigfield, A. (1998). Academic and social motivational influences on students' academic performance. Educational Psychology Review, 10(2), 155175.

Winsler, A., Hutchison, L. A., De Feyter, J. J., Manfra, L., Bleiker, C., Hartman, S. C., \& Levitt, J. (2012). Child, family, and childcare predictors of delayed school entry and kindergarten retention among linguistically and ethnically diverse children. Developmental Psychology, 48(5), 1299-1314.

Yang, M-Y., Chen, Z., Rhodes, J. L.F., \& Orooji, M. (2018). A longitudinal study on risk factors of grade retention among elementary school students using a multilevel analysis: Focusing on material hardship and lack of school engagement. Children and Youth Services Review, 88, 25-32 